\title{
THE ROLE OF SOCIAL NETWORKS IN CYBER-DIPLOMACY IN THE CONTEXT OF 5G
}

\section{DANIEL MUÑOZ-SASTRE}

daniel.munoz.sastre@uva.es PhD in Audiovisual Communication and Advertising. Lecturer at the University of Valladolid where he teaches the subjects of Culture and Corporate Identity and Brand Management. Member of the Research Group on Trends in Advertising and Consumption of the Icono 14 Association. He has been editor-in-chief at the two main Spanish radio stations, SER and COPE, advisor to various companies and institutions on corporate identity issues and contributor to the candidacy of Segovia (Spain) for European Capital of Culture in 2016.

ISABEL RODRIGO-MARTÍN isabel.rodrigo@uva.es PhD in Audiovisual Communication and Advertising and Master's in communication with Social Purges: Strategies and Campaigns from the University of Valladolid. Senior Lecturer at the University of Valladolid. He has won the Caja España 2007 research prize and the IV Research Scholarship of the Institute of Traditional Segovian Culture of the Provincial Council of Segovia. She is a researcher at the Complutense University of Madrid (Spain) in the Chair of Digital Communication in Childhood and Adolescence and in the SocMedia Research Group.

\section{LUIS RODRIGO-MARTÍN}

luis.rodrigo@uva.es

PhD in Audiovisual Communication and Advertising and Bachelor of Law. Senior Lecturer at the University of Valladolid (Spain). He has been recognized with the Caja España and Caja Segovia research prizes for two projects related to communication and consumption. Researcher of the Complutense Chair of Communication and Marketing in Childhood and Adolescence. He is the author of several books and about thirty articles in scientific journals. He was Director of Communication of the Segovia Campus of the University of Valladolid.

\section{Abstract}

The implementation of the $5 \mathrm{G}$ network has led to one of the most serious diplomatic clashes in recent years. The commercial war between the United States and China to lead the development of the fifth generation of mobile Internet is being fought, among other battlefields, on social networks. Our research analyzes the role of these communication tools in the framework of this international conflict. It examines the use of social networks and their value in the development of what is known as cyber-diplomacy. At the same time, we look into the decisions taken by both states aimed at banning the activity of certain social networks in their respective territories. The study shows the importance of social networks in the transmission of messages between the contending parties and how they use them to attack and defend their respective interests.

\section{Keywords}

Cyber-diplomacy; social networks; 5G; United States; China

How to cite this article

Muñoz-Sastre, Daniel; Rodrigo-Martín, Isabel; Rodrigo-Martín, Luís. The role of social networks in cyber-diplomacy in the context of 5G. Janus.net, e-journal of international relations. Thematic dossier International Relations and Social Networks, July 2021. Consulted[online] in date of the last visit, https://doi.org/10.26619/1647-7251.DT21.1

Article received on em January 4, 2021 and accepted for publication on March 22, 2021

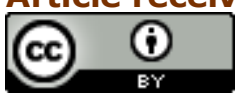




\section{THE ROLE OF SOCIAL NETWORKS IN CYBER-DIPLOMACY} IN THE CONTEXT OF $\mathbf{5 G}^{1}$

\section{Introduction}

The unstoppable digital transformation underway since the beginning of the $21^{\text {st }}$ century is not limited to the incorporation of technological tools and processes in all areas of lifefrom the industrial to the domestic sector, including everything related to governance. This process is shaping a new world order, with new balances and imbalances. It is a race full of opportunities for states that have hitherto played a secondary role on the international scene, while posing new threats to the traditionally dominant countries. The battle to drive this change began with the imposition of trade restrictions through heavy tariffs, thus aggravating tensions and escalating the risk of confrontation between those states aspiring to lead the international order.

The World Economic Forum already warned about the role of new technologies in this reconfiguration of the world scene in its Global Risks Report 2018 (World Economic Forum, 2018: 7). It pointed to the cybernetic sphere as a source of tensions leading to potential conflicts in a context of new alliances and market configurations. Three years later, the Global Risks Report 2021 lists digital power concentration and digital inequality among the seven main global risks for this year (World Economic Forum, 2021: 14). The World Economic Forum also warns that political confrontation between states may affect the activity of some companies (World Economic Forum, 2021: 65).

The importance of technology in international relations is best illustrated by the escalating confrontation between the United States and China over technological leadership, and in particular the development of the fifth generation mobile Internet $(5 \mathrm{G})$. China's growing economic, military and technological power has led to a rebalance of power in a world order hitherto dominated by the United States. That is why some authors focus on their bilateral relation as the most relevant for the $21^{\text {st }}$ century (Sutter, 2011: 1). Their ongoing struggle has prompted other governments to implement measures such as tariffs on technological products (Natixis, 2018). The development and deployment of $5 G$ networks goes beyond the realm of technology and enters into geopolitics (Morozov, 2020).

1 Article translated by Frutos Miranda Traductores. 
The ill feeling between the United States and China is not new, nor did it originate with the arrival of 5G. Disagreements have been going on for a long time and in recent decades tensions between the two countries have been constant. The Clinton administration already threatened the Asian giant. However, the intervention of some of the most prominent American companies with interests in China helped to defuse the tension-which again escalated during Trump's presidency. Some analysts consider that this confrontation goes beyond a specific moment or context, and that it will underpin all future relations between both countries, since "anti-China sentiment runs deep in both parties in Congress. Tariffs have become normalized weapons. That will continue to push Washington and Beijing on a collision course, no matter who occupies the White House" (Chon, 2020).

The novelty of the current contention lies in the increasing role and use of social networks in institutional relations, leading to so-called digital diplomacy or cyber-diplomacy, analyzed among others by Maccarthy (2015) and Manfredi Sánchez, according to whom, "digital diplomacy provides an opportunity for political participation, activism and agenda setting" (Manfredi Sánchez, 2014: 352). The presence of social networks in the diplomatic sphere has become commonplace, whether through accounts belonging to public agencies or to political leaders: "Social networks are part of the communicative reality of today's international society and are undoubtedly becoming the battlefield of the $21^{\text {st }}$ century" (Rodríguez Cela, Parras-Parras and Romero-Vara 2019: 723).

The study of how social networks affect international politics becomes even more interesting due to the intense activity of President Trump during his term in office. Trump's regular use of Twitter to make public announcements of all kinds through his personal account @realDonaldTrump (including the dismissal of staff, threats to other countries' leaders, and his opinions on different current issues) made this social network one of the most important references to know the intentions of the American president. Furthermore, these publications made by Trump throughout all these years provide a historical document for the assessment of his administration.

The use of social networks raises the following issues:

- Analyzing the use of social networks in cyber-diplomacy regarding the implementation of $5 \mathrm{G}$.

- Understanding the intent of the messages published on official government accounts.

- Determining the main concepts included in these messages.

- Studying the decisions of both governments regarding the activity of different social networks in their respective territories.

This study is part of a broader project on the deployment of 5G networks, which began in 2018 to assess the impact of this new technology on different environments-including digital social platforms (Muñoz-Sastre at al., 2019). This paper focuses on the role of social networks, and specifically Twitter, in the confrontation between the United States and China over the global implementation of the fifth generation of mobile Internet. All the above leads to the following initial hypothesis: 
$\mathrm{H} 1$. The agreements and disagreements between the US and China aired through social networks in recent years regarding the implementation of 56 bring a new scenario for international relations-that of cyber-diplomacy-with social networks as a key player.

\section{Methodology}

The time frame of the study covers Trump's presidency, between 20 January 2017 and 20 January 2021, which includes the moments of greatest tension between the US and China. This period coincides with the beginning of the works for the implementation and commercial exploitation of $5 G$ networks. We focus on Twitter because it registered the highest activity concerning 5G from official accounts linked to the US and China, or some of their main leaders (see Table 1).

Table 1. List of Twitter accounts analyzed

\begin{tabular}{|l|c|r|}
\hline \multicolumn{1}{|c|}{ ACCOUNT } & US & LINK \\
\hline @WhiteHouse & US & https://twitter.com/WhiteHouse \\
\hline @realDonaldTrump & US $/ /$ twitter.com/realDonaldTrump \\
\hline @StateDept & US & https://twitter.com/StateDept \\
\hline @SecPompeo & US & https://twitter.com/SecPompeo \\
\hline @USA_China_Talk & China & https://twitter.com/USA_China_Talk \\
\hline @zlj517 & China & https://twitter.com/MFA_China \\
\hline @MFA_China & China & https://twitter.com/ChineseEmbinUS \\
\hline @ChineseEmbinUS & China & https://twitter.com/chinascio \\
\hline @chinascio & &
\end{tabular}

Source: own compilation.

For the selection of the study sample, we reviewed all messages published by these accounts directly linked the subject matter, obtaining a sample of 275 messages (133 from Chinese accounts and 142 from US accounts). Subsequently, we carried out a quantitative and qualitative analysis of the messages. This retrospective study is observational, analytic, and explanatory, without any manipulation of the variables. We analyzed the publications in depth to identify their effects on the relations between these two world powers. The research consists of three stages as shown in Table 2:

Table 2. Research stages

\begin{tabular}{|c|c|c|}
\hline STAGE & SCOPE & OBJECTIVES \\
\hline \multirow{2}{*}{1} & \multirow{2}{*}{ Theoretical framework } & Approach to the object of study \\
\hline & & Contextualization and conceptualization \\
\hline \multirow{2}{*}{2} & \multirow{2}{*}{ Message analysis } & Study sample selection \\
\hline & & Sample analysis \\
\hline \multirow{2}{*}{3} & \multirow{2}{*}{ Discussion } & Search for answers \\
\hline & & Findings \\
\hline
\end{tabular}

Source: own compilation. 
Taking into account the objectives and hypothesis of this study, the variables considered are:

- The number of messages published on the different accounts.

- The tone used in those posts.

- The decision-making by both governments.

\section{New forms of diplomacy}

\section{From traditional diplomacy to cyber-diplomacy}

Diplomacy, defined by Kissinger (1955: 8) as "the art of relating states to each other by agreement rather than by the exercise of force", is a practice that dates back to antiquity. It has undergone major transformations throughout history. Initially, it had an itinerant nature, linked to a specific contact or negotiation between states. It then became permanent in the $15^{\text {th }}$ century through the diplomatic practices implemented by the Holy See and later developed by the Italian states-mainly Venice, considered the forerunner of modern diplomacy (Calduch Cervera, 1993).

However, until World War I, relations and agreements between states remained secret. It was not until January 1918, ten months before the end of the conflict, that US President Woodrow Wilson delivered a speech to the Congress outlining his proposals to ensure peace, begin the reconstruction of Europe, and establish a new international order. In his fourteen points, Wilson advocated "open agreements and no secret diplomacy in the future" (Cátedra de Derecho Internacional Público de la Universidad Católica de la Plata, 2010).

This statement marks the beginning of what is known as public diplomacy, an approach to international relations that involves citizens in the agreements and disagreements between countries. Professor Gilboa (2008) addresses the study of public diplomacy from a multidisciplinary perspective, ranging from the field of diplomacy to that of communication, including international and public relations. In one of his works, Gilboa (2000) incisively reflects on the relationship between current diplomacy and the media, presenting six conceptual models to study this connection.

Technologies such as the radio, the television or the Internet have played a major role in opening diplomacy to the public. In particular, the Internet is essential in the ongoing transformation of international relations. Indeed, cyber-diplomacy is defined as the digitalization of this field of politics. In the words of Prof. Rafael Rubio, we face "an extension of public diplomacy allowing states to participate in distributed information networks" (Rubio, 2011: 44).

\section{The role of social networks in cyber-diplomacy}

For some time now, social networks have become increasingly relevant in the field of diplomacy. As pointed out by Rodríguez Gómez (2015: 926), "This 2.0 universe of social networks provides the ministries of foreign affairs with tools that should be used for their socializing and globalizing potential, as well as for their bidirectionality and, therefore, 
their feedback capacity." Manfredi Sánchez (2013) also refers to the centrality of social networks in diplomacy: "Social networks provide new opportunities for the participation of non-state actors, paving the way for public diplomacy and the achievement of political objectives." In a similar vein, Grossman (2006) considers that social networks offer an opportunity to advance international relations beyond the meeting of politicians or leaders to an understanding between people.

The presence of governments and leaders in social networks has gradually increased in recent years. Since 2018 Twitter is considered the social network of choice for governments and world leaders (Burson Cohn \& Wolfe, Ltd, 2018). According to the Twiplomacy study $2020,98 \%$ of UN member states are present on social networks. Only four countries (Laos, North Korea, Sao Tome and Principe, and Turkmenistan) lack accounts on that social network (Burson Cohn \& Wolfe, Ltd, 2020). As far as leaders are concerned, Donald Trump heads the list of world leaders with the largest number of followers on Twitter, over 88 million according to the last figure registered in his personal account on the day it was suspended (Brown, 2021).

Aware of the potential impact of messages posted on social networks, several governments and supranational institutions have developed regulations for their use in the field of cyber-diplomacy. See, for instance, the Council Conclusions on Cyber Diplomacy, adopted by the Council of the European Union (2015), or the digital diplomacy plans drawn up by countries such as France (Ministère de l'Europe et des Affaires étrangères, 2017) and Spain (Ministerio de Asuntos Exteriores, Unión Europea y Cooperación. Gobierno de España, 2015). All of them provide guidelines on the use of these new technologies, including social networks, in the field of diplomacy.

\section{The US-China conflict via Twitter}

As already mentioned, US-China relations are among the most relevant elements from the point of view of diplomacy in the first decades of the $21^{\text {st }}$ century, with moments of greater and lesser tension in these last years. During this time, the US has regarded China as a strategic partner on some occasions and as a strategic competitor on others. Despite these differences, many experts agree that these two countries are doomed to understand each other (Bustelo and Soto, 2003).

However, the development of the fifth generation of mobile Internet has heightened the tension between both powers over the control of a technology with infinite capabilities that has become key in shaping the new world order. Both the US and China acknowledge the importance of $5 G$, although with some differences in their respective positions. As pointed out by Jinghua (2020), this is a race that America must win, while for China it represents a major leap in the field of information and communication technologies.

The governments and some leaders of both countries have taken this rivalry to social networks, particularly Twitter. Nine official accounts, two personal accounts and seven institutional accounts directly linked to these administrations show an important activity in terms of messages about $5 \mathrm{G}$.

A total of 275 publications on the fifth generation of mobile Internet were published by the most prominent official accounts of both countries. Most of these messages are written in English (83\%), and only those published by the US Embassy in China are 
written in the language of the Asian giant. It is worth noting that most publications post original content created by the account owners ( $84 \%)$, while the rest (16\%) are retweets from other accounts. US profiles show the highest number of retweeted messages. Also relevant is the message impact analysis, which shows a significant difference between posts from US and Chinese profiles (Chart 1).

When it comes to the intent of those publications, most of them seek to extol the capacity, technological power and influence of each country, or to present their achievements, whether technical or diplomatic. See for instance the Clean Network, a US-led initiative that brought together an alliance of countries opposed to the implementation of Chinese-backed 5G technology. The analysis of the sample messages showed a third objective: to attack the opponent (Chart 2). When analyzed by country, it can be seen that US messages mainly seek to warn about the risks associated with Chinese technology and to undermine its interests. On the other hand, messages from accounts linked to the Chinese government essentially aim at defending against such attacks and praising the technological capacity of the Asian giant (Chart 3).

Chart 1. Message impact by country (absolute data).

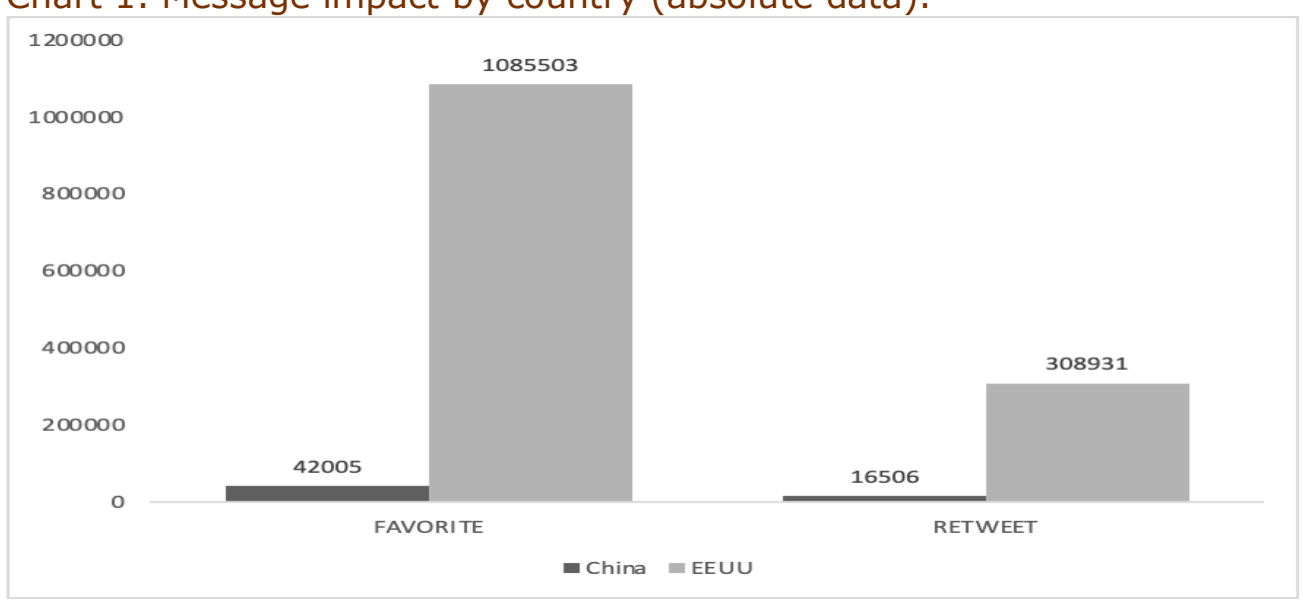

Source: own compilation.

Chart 2. Message intent (\%)

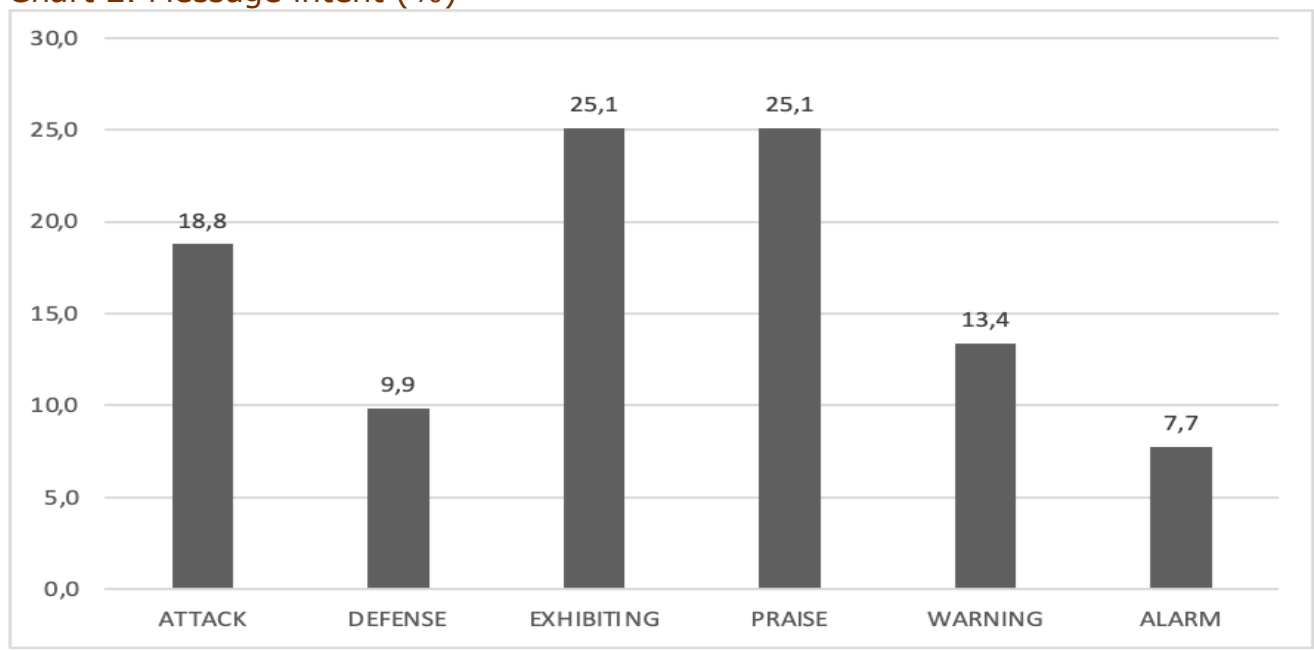

Source: own compilation. 
Chart 3. Message intent by country (\%)

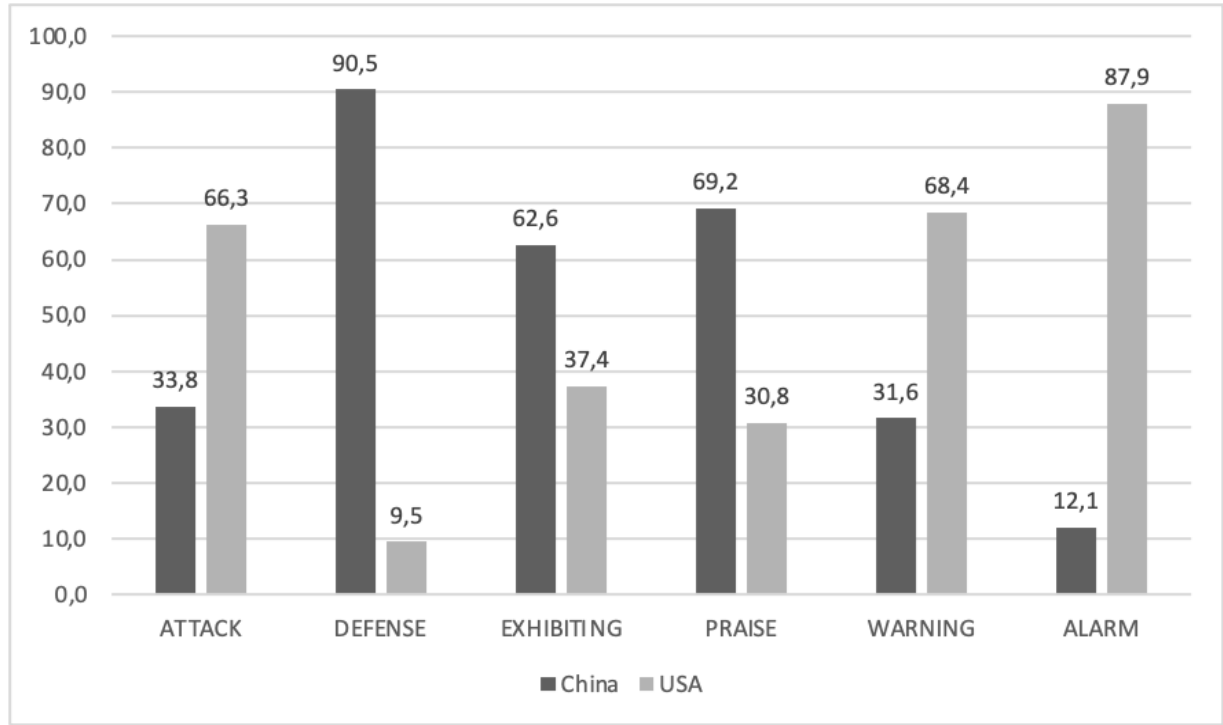

Source: own compilation.

Security and privacy issues are among the most mentioned in the analyzed posts, only after direct references to China and the US-almost ubiquitous. Behind them are other topics such as the alleged threats posed by the implementation of $5 \mathrm{G}$ networks, references to communism or the Chinese Communist Party, and to human rights. Notions such as trust, democracy or human rights only appear in messages from US accountsas opposed to references to China, the US, and freedom, that prevail in Chinese posts (Chart 4).

Chart 4. Concept relevance by country (\%)

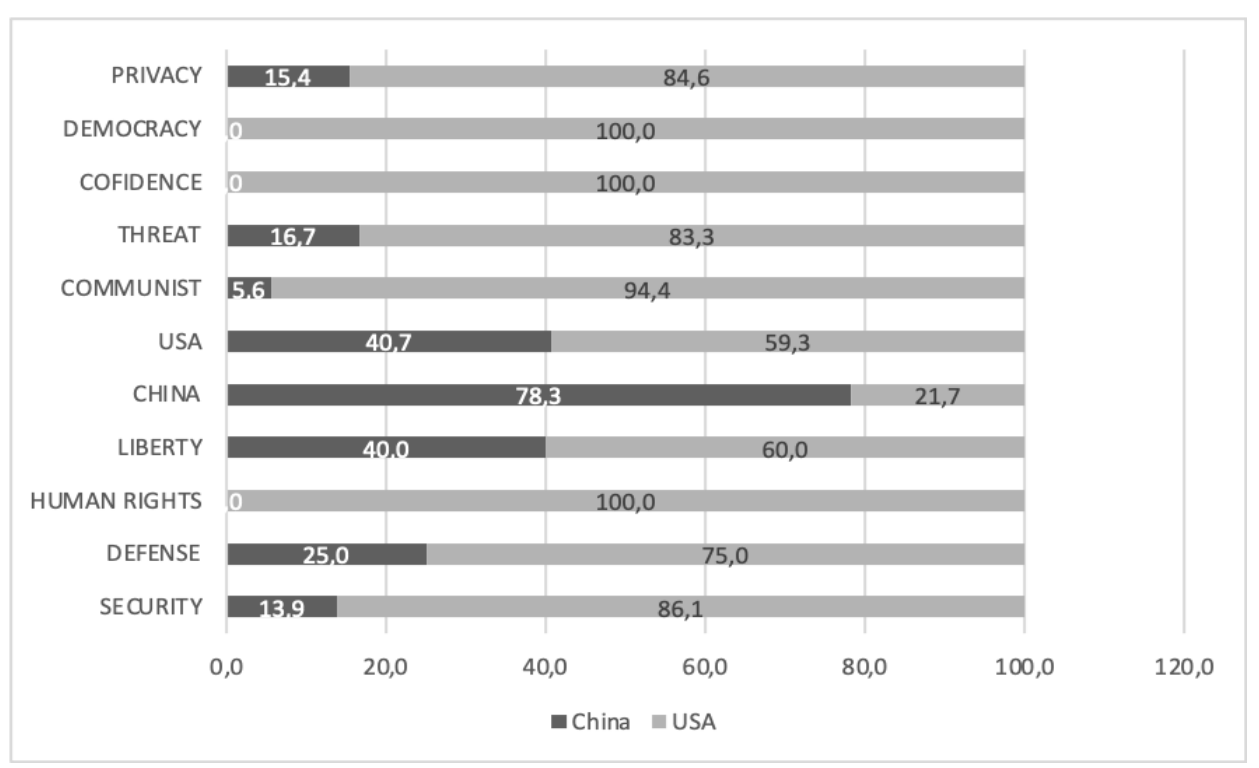

Source: own compilation. 
Also remarkable is the evolution of publications related to $5 \mathrm{G}$ over the reference period. According to our study, it was not until the spring of 2019 that the messages on the fifth generation of mobile Internet increased exponentially. In April and May of that year, both countries intensified their activity on Twitter with different purposes: extolling their own technological capacity, questioning their opponent's technology, and accusing each other of bad practices. The online confrontation subsequently escalated in November and December 2019, as well as in May and July 2020 (Chart 5). Another spike was recorded at the end of 2020 and in the first weeks of 2021, coinciding with the final days of Trump's presidency-prompting the researchers to extend the study to include that period.

Chart 5. Evolution of publications (absolute data)

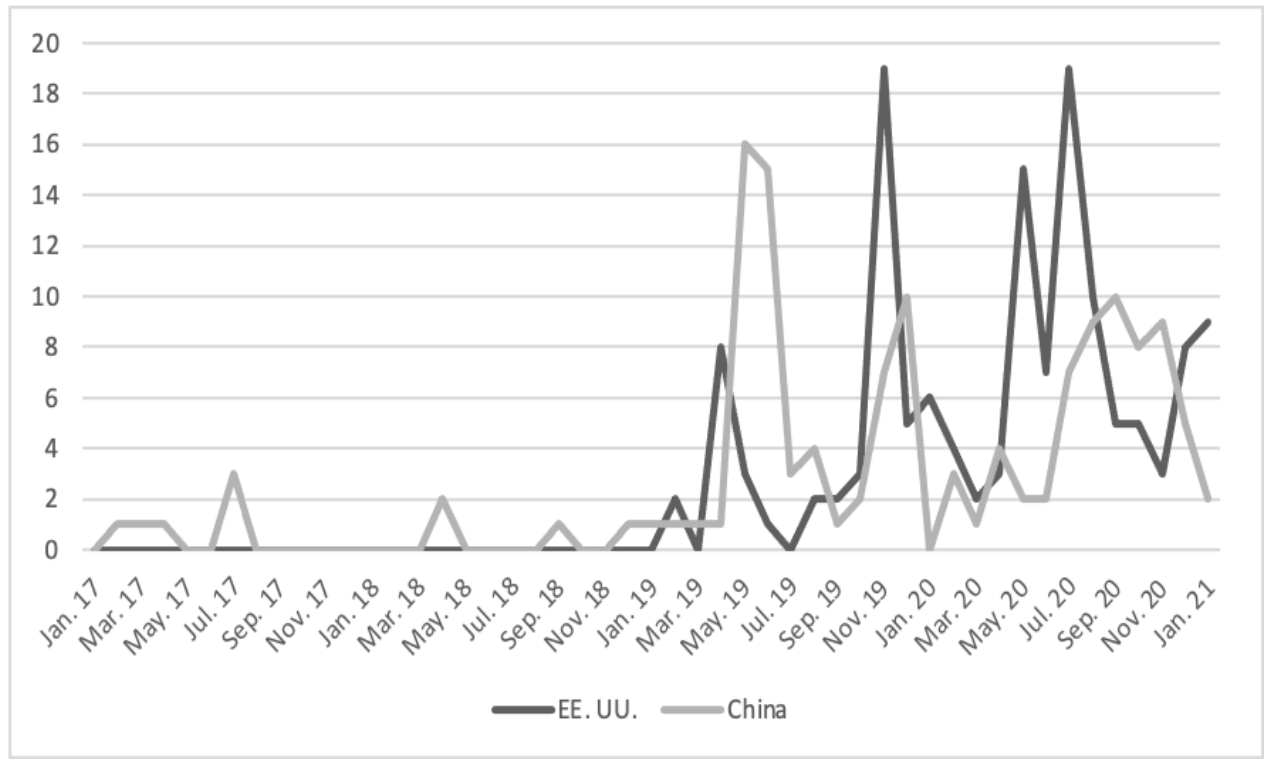

Source: own compilation.

The messages posted during those three periods of particular intensity have similar purposes and refer to the same concepts. However, the second spike shows several publications regarding the arrest in Canada of Huawei's deputy chair and CFO-Huawei being the leading Chinese technology company and 5G champion. In that period there are also messages about the possible banning of Chinese apps such as TikTok in the US. In the third period of maximum intensity there are constant messages from the US about the Clean Network international alliance. Figure 1 shows some messages to illustrate this tension between both countries. 
Figure 1. Example of diplomatic confrontation between the US and China.

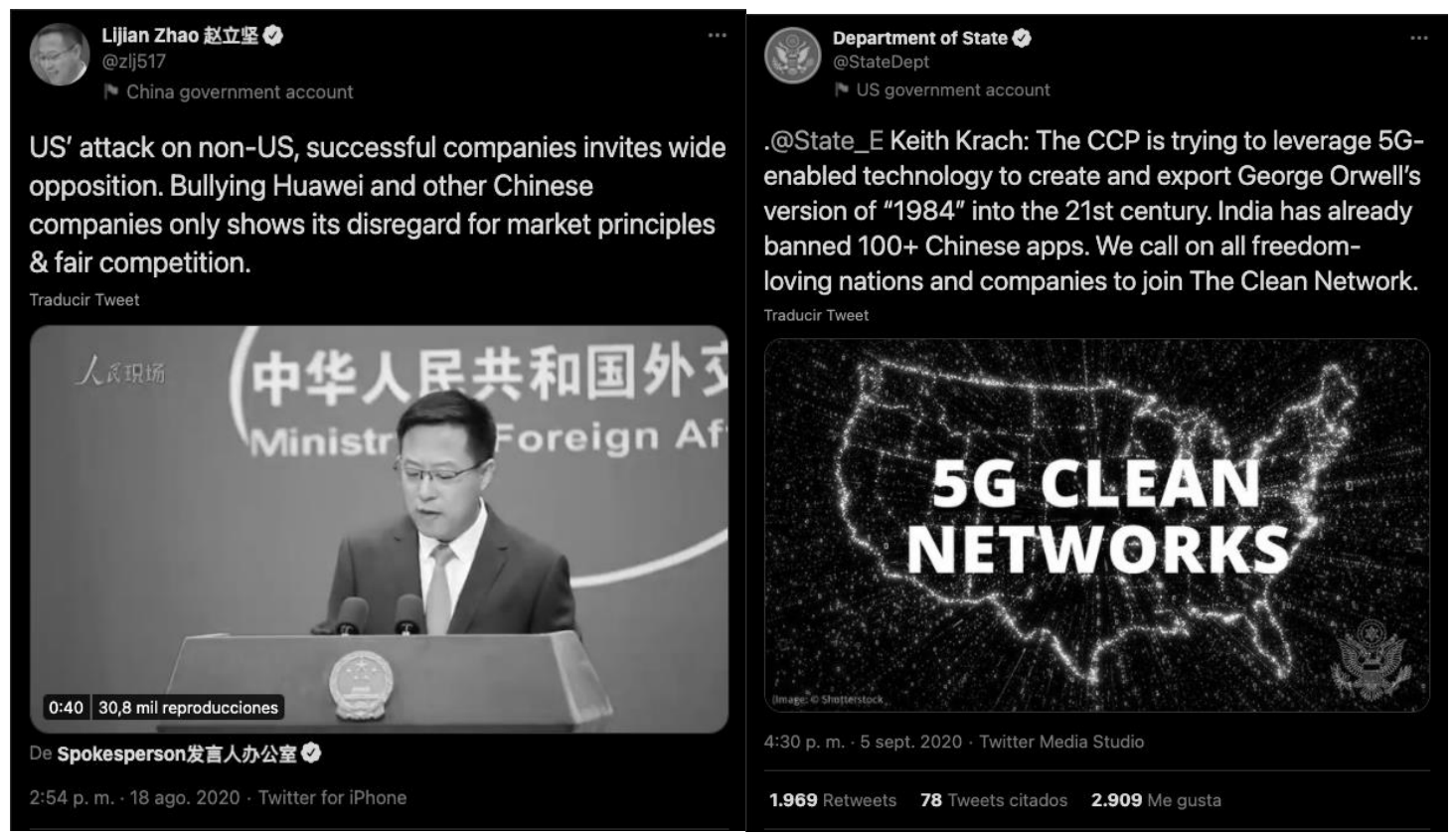

Source: Zhao (2020) and the US Department of State (2020).

Finally, the study provides a detailed analysis of each profile by number of publications on this technology:

- @chinascio is the official account of the State Council Information Office of China, active since September 2015, with around 44,500 followers. During the analyzed period, it published a total of 67 messages regarding $5 G$ technology -65 of which with own content and 2 retweets, receiving 488 "likes" and 206 retweets. Most of its messages are expository and praise China's technological potential.

- @zlj517 is the official personal account of the spokesman and deputy director general of the Information Department of China's Ministry of Foreign Affairs. He joined Twitter in May 2010 and has over 879,900 followers. This account has published 49 messages related to the fifth generation of mobile Internet, 47 of which are own content and 2 are shared from other accounts. It is the Chinese profile with the most followers and responses to its publications, most of which defend Chinese interests and attack US comments and measures, once even launching a warning. He insistently repeats the names of both countries.

- @USA_China_Talk is the account of the US Embassy in China. Active since 2009, it has approximately $1,147,000$ followers. It is the only account analyzed that posts its messages in Chinese. Of its 46 publications on the subject matter, most are retweets from accounts linked to the US administration. The tone of its messages is mostly aggressive and warning, and after the name of both countries the concepts most mentioned are security and privacy.

- @SecPompeo is the profile of the US Secretary of State during Donald Trump's presidency. This account was opened in April 2018, it has just over three million followers and it has remained inactive since the end of Trump's term in office. With 41 
messages on 5G, all of them his own, it is arguably the most active US profile on this social network and, after President Trump's, the one that generates the greatest response from Internet users with more than 315,600 "likes" and 89,500 retweets of its publications about that technology. These messages are mostly of an expository nature, extolling US capabilities and attacking the Asian giant. Security is among the most mentioned issues in Pompeo's posts.

- @StateDept is the official account of the US State Department and has been active since 2007. It has more than 6 million followers and during the period analyzed it published 37 messages related to 5G, all of them its own. However, in terms of impact, these posts did not reach the response elicited by the messages published by the head of the department on his personal account. Most of the messages are attacks against the Asian rival and warnings both to China and third countries. References to security, communism and privacy are common.

- @realDonaldTrump is President Donald Trump's personal profile. It is among the most followed accounts, with 88.7 million followers, and one of the most controversial, to the point that Twitter decided to suspend it in January 2021, twelve years after its creation. Although it is not the account with the highest number of posts related to $5 \mathrm{G}$ (only 13), they get the most reactions of the entire study, with about 682,000 "likes" and 188,000 retweets. In these publications, Trump mainly warns China and other countries to follow Washington's indications and exposes US technological potential. Among the most frequently used terms are those related to security, the very name of the United States and communism.

- @MFA_China is the official account of China's Ministry of Foreign Affairs. Created in October 2019, it has just over 247,500 followers. During the analyzed period, it published a dozen messages linked to 5G, all of them its own. They have little impact, with just over 3,300 "likes" and 744 retweets. Most of these messages are intended to defend against accusations or attacks from the United States or to warn against attacks on China's interests. Words such as China, United States or security are the most repeated.

- @ChineseEmbinUS is the profile of the Chinese Embassy in the United States, created in 2019 and with about 83,000 followers. It published seven messages about 5G, four of which are retweeted content from other sources. It elicited fewer responses than the rest of the accounts studied, with 313 "likes" and 89 retweets. Its posts on the fifth generation of mobile Internet seek to extol China's technological development potential.

- @WhiteHouse: is the official White House account. It was opened in 2016 but, like the President's official one (@POTUS), it is archived every time the tenant of the US presidential residence changes. During Trump's four years in office, five messages related to $5 \mathrm{G}$ were published from this account, all of them its own and fundamentally aimed at praising the capacity of the US. Unsurprisingly, the name of the country is the most repeated. 


\section{Discussion}

In light of the analysis carried out, social networks are not mere communication tools within the field of diplomacy. Rather, they are key instruments for the development of international relations. By enabling citizen involvement in these relations, social platforms are a perfect embodiment of open diplomacy and cyber-diplomacy.

In the case of 5G, this openness is illustrated by the type of messages published by the Chinese and US administrations or by some of their most prominent leaders. The initial hypothesis is fully confirmed, as can be seen in the message exchange between both powers through different Twitter accounts.

From the gathered data, there is a noteworthy difference in the nature of the messages published by accounts from each country. While Chinese posts are more defensive or aimed at praising the country or advancing its interests, those from the US are mostly in a warning and threatening tone. This is also the case with the most repeated terms. While US accounts insist on concepts such as democracy, trust or human rights, the terms most often mentioned in Chinese publications are China, the US, and freedom. All this closely reflects the policy approach of each government.

\section{Conclusions}

This study shows how the diplomatic use of social networks makes it possible to analyze the political agenda in the context of the relations between two or more countries. Hence, issues such as US actions against Huawei or the restrictions that the Trump administration intended to impose on networks such as TikTok burst into the digital scene and become not only political issues but also matters of public debate.

On the other hand, one of the essential purposes of cyber-diplomacy is to influence international public opinion, as shown in this case by the intent and content of the messages. This study shows that social networks, and specifically Twitter, are used to attack the opponent, to defend against his accusations, for self-congratulation, as well as to warn of possible consequences or alleged risks. Issues such as security, defense, privacy, freedom or human rights are raised in a large number of the messages analyzed. None of these terms and concepts go unnoticed by citizens and they have a great mobilization capacity around certain causes.

Finally, the message impact analysis leads to another conclusion: the personal nature of Trump's presidency. Even if he is not the one who tweeted the most about 5G during these years, the messages from his personal account are the ones that get the most "likes" or retweets. This fact highlights the personification of diplomacy, until now not so visible to society, but nonetheless a reality within the currently developing model of cyber-diplomacy-thus paving a new way for conducting international relations in the $21^{\text {st }}$ century.

\section{References}

Brown, B. (2021). Trump Twitter Archive. [online] Thetrumparchive.com. [29 Jan. 2021]. Available at: https://tinyurl.com/2bl5g94s 
Burson Cohn \& Wolfe, Ltd (2018). Twiplomacy Study 2018. [online] Twiplomacy. Burson Cohn \& Wolfe, Ltd. [14 Nov. 2020]. Available at: https://tinyurl.com/1273rnce

Burson Cohn \& Wolfe, Ltd (2020). Twiplomacy 2020. [online]. [17 Nov. 2020]. Available at: https://tinyurl.com/1tsyzkui

Bustelo, P. and Soto, A. (2003). Las relaciones entre Estados Unidos y China: casociación o competencia estratégicas? [online] Realinstitutoelcano.org. Madrid: Real Instituto Elcano. [13 Oct. 2020]. Available at: https://tinyurl.com/38efv2le

Calduch Cervera, R. (1993). Dinámica de la sociedad internacional. Madrid: Editorial Centro de Estudios Ramón Areces.

Castells, M. (2005). La sociedad red. Madrid: Alianza.

Cátedra de Derecho Internacional Público de la Universidad Católica de la Plata (2010). Catorce puntos del Presidente Wilson (1918). [online] Dipublico.org. [11 Sep. 2020]. Available at: https://tinyurl.com/tarvrlam

Chon, G. (2020). Trump's fight with China will outlast him. [online] Reuters.com. [27 Jan. 2021]. Available at: https://tinyurl.com/y2tbnhms

Consejo de la Unión Europea (2015). Conclusiones del Consejo sobre la ciberdiplomacia. [14 Sep. 2020]. Available at: https://tinyurl.com/d5nvbw0d

Departament of State U.S. (2020). .@State_E Keith Krach: The CCP is trying to leverage 5G-enabled technology to create and export George Orwell's version of... [Tuit] [23 Dec. 2020]. Available at: https://tinyurl.com/qlob1550

Fuente Cobo, I. (2019). La geopolítica en la era posdigital. Boletín IEEE, [online] (15), pp.248-260. Available at: https://tinyurl.com/y5m986wz

Fundación Real Instituto Elcano, 2002-2016 (2020). Inicio. [online] Realinstitutoelcano.org. [7 Jan. 2021]. Available at: http://www.realinstitutoelcano.org/wps/portal/rielcano_es/contenido?WCM_GLOBAL_C ONTEXT=/elcano/elcano es/zonas es/dt30-2003

Gilboa, E. (2000). Mass Communication and Diplomacy: A Theoretical Framework. Communication Theory, [online] 10(3), pp.275-309. [22 Mar. 2021]. Available at: https://academic.oup.com/ct/article-abstract/10/3/275/4210393

Gilboa, E. (2008). Searching for a Theory of Public Diplomacy. The Annals of the American Academy of Political and Social Science, 616(1), pp.55-77.

González, A., Jiménez, C., Navarro, D., Páez, E., Salazar, E., Cruz, M., Pérez, M., Bertolini, P., Romero, V. and Contreras, V. (2021). Trump y su legado digital: 4 años de confrontaciones tecnológicas. [online] digitalpolicylaw.com, México D.F.: Digital Policy \& Law Group, pp.1-54. [21 Jan. 2021]. Available at: https://tinyurl.com/y4ajjfv2

Grossman, L. (2006). Time's Person of the Year: You. Time Magazine. [online] 13 Dec. [2 Nov. 2020]. Available at: https://tinyurl.com/mg7srtsm

Heine, J. (2013). La Paradoja de Twitter en Diplomacia. [online] Other-news.info. [28 Jan. 2021]. Available at: https://tinyurl.com/4jqebdm0 
Jinghua, L. (2020). The Race of Chinese Companies in the 5G Competition. In: S. Dominioni and F. Rugge, eds., Dossier ISPI Septiembre 2020: La geopolítica del 5G. [online] Italian Institute for International Political Studies, pp.15-17. [9 Nov. 2020]. Available at: https://tinyurl.com/139miqcr

Kissinger, H.A. (1955). The Limitations of Diplomacy. The New Republic, [online] (), pp.7-8. [4 Sep. 2020]. Available at: https://tinyurl.com/jl6qpnc8

Manfredi Sánchez, J.L. (2013). El desafío de la diplomacia digital. [online] Realinstitutoelcano.org. [7 Sep. 2020]. Available at: https://tinyurl.com/bpjukuf8

Manfredi Sánchez, J.L. (2014). Taxonomía de la diplomacia digital en la agenda de las nuevas relaciones internacionales. Historia y Comunicación Social, [online] 19(0). [11 Dec. 2020]. Available at: https://tinyurl.com/17byxvwy

Manor, I. and Segev, E. (2015). America's selfie: How the US portrays itself on its social media accounts. In: Digital Diplomacy: Theory and Practice. Routledge.

Mccarthy, D. (2015). Power, information technology, and international relations theory the power and politics of US foreign policy and internet. London, UK: Palgrave Macmillan.

Ministère de l'Europe et des Affaires étrangères (2017). Diplomatie numérique. [online] France Diplomatie - Ministère de I'Europe et des Affaires étrangères. [11 Feb. 2021]. Available at: https://www.diplomatie.gouv.fr/fr/politique-etrangere-de-lafrance/diplomatie-numerique/

Ministerio de Asuntos Exteriores, Unión Europea y Cooperación. Gobierno de España (2015). Atención al ciudadano y diplomacia digital. [online] Exteriores.gob.es. [11 Nov. 2020]. Available at: https://tinyurl.com/2hgamyq

Moret Millás, V. (2019). El despliegue de las redes 5G, o la geopolítica digital. CIBER Elcano, [online] (42). [27 Jan. 2021]. Available at: https://tinyurl.com/yx98g7sw

Morozov, E. (2020). Batalla geopolítica en torno al 5G. Le Monde Diplomatique en español, [online] (300), Oct., pp.26-28. y3qycyaf [27 Jan. 2021]. Available at: https://tinyurl.com/

Muñoz-Sastre, D., Rodrigo-Martín, I. and Rodrigo-Martín, L. (2019). La transformación de las plataformas sociales digitales en la quinta generación de internet móvil: oportunidades y amenazas. In: Redes sociales, tecnologías digitales y narrativas interactivas en la sociedad de la información. Madrid: McGraw-Hill, pp.423-435.

Natixis (2018). Our key take-away on US-China trade war. [online] Natixis.com. [27 Jan. 2021]. Available at: https://tinyurl.com/y6kxexm6

R. Cela, J., Parras-Parras, A. and Romero-Vara, L. (2019). Uso de las redes sociales en diplomacia, política y relaciones internacionales. Análisis de la información publicada en las versiones online de dos periódicos españoles: "El País" y "La Vanguardia." Estudios Sobre El Mensaje Periodístico, [online] 25(2), pp.711-726. [28 Jan. 2021]. Available at: https://tinyurl.com/3nzpe3g3

Rodríguez Gómez, A.A. (2015). Diplomacia digital, cadaptación al mundo digital o nuevo modelo de diplomacia? Opción, [online] (Especial 2), pp.915-937. [3 Oct. 2020]. Available at: https://tinyurl.com/rOcsbi2u 
Rubio, R. (2011). Diplomacia digital. Una introducción. Cuadernos de la Escuela Diplomática, (44), pp.29-56.

Seib, P. (2012). Real-time diplomacy: politics and power in the social media era. New York: Palgrave Macmillan.

Sutter, R. (2011). Positive equilibrium in U.S. - China Relations: Durable or not? JANUS.NET e-journal of International Relations, [online] 2(1), pp.1-13. [2 Oct. 2020]. Available at: https://tinyurl.com/1c7wmuqz

Westcott, N. (2008). Digital Diplomacy: The Impact of the Internet on International Relations. Oxford Internet Institute Working Paper, [online] (16). Available at: https://tinyurl.com/1svq66j2

World Economic Forum (2018). The Global Risks Report 2018. [online] weforum.org. Geneva, Switzerland: World Economic Forum. Available at: https://tinyurl.com/y6dpa5hd

World Economic Forum (2021). The Global Risks Report 2021. [online] weforum.org. Geneva, Switzerland: World Economic Forum. Available at: https://tinyurl.com/y2ean4la 